
COASTAL ENGINEERING 
Chapter 44

SAND TRANSFER, BEACH CONTROL, AND INLET IMPROVEMENTS,
FIRE ISLAND INLET TO JONES BEACH, NEW YORK,

Thorndike Saville

Consultant, Long Island State Park Comnission; Consultant to the President, University of Florida;

Dean Emeritus, New York University.

\section{LOCATION AND GEOMORPHOLOGY}

Long Island, New York (Figure 1) extends for about 120 miles in a general east-west direction off the southern portions of the States of New York and Connecticut, from which it is separated by Long Island Sound. The western end of the island contains the Counties of Brooklyn and Queens which are part of New York City. To the east are the Counties of Nassau and Suffolk. The surface geology of Long Island is mostly of glacial origin. That portion of the south shore of Long Island with which this paper is concerned (Figure 2) consists of outwash plains of sand and gravel fringed by barrier beaches from 600 feet to 3,500 feet in width. They rise to about 15 feet above mean sea leve1, and in their natural condition are more or less protected by sand dunes which may reach an elevation of from 25 feet to 30 feet.

The sand along the foreshore is predominantly quartz, averaging about $0.4 \mathrm{~mm}$. at mid-tide level, and becoming somewhat finer offshore. The foreshore slope of the beaches averages about 1 on 10 above the mean $10 \mathrm{w}$ water 1 ine and about 1 on 30 immediately offshore. Several hundred feet offshore the slope flattens to about 1 on 250 .

\section{THE PROBLEM AREA}

GENERAI.

This paper deals with problems of beach protection and restoration, and inlet improvements in the area from Jones Inlet to a point on Fire Island some five miles east of Fire Island Inlet, as indicated on Figure 2. Probably no coastal area in the United States has been subject to such long continued and exhaustive studies of coastal phenomena as this. It constitutes 23 miles of publicly owned beach developed and intensively used for recreational purposes and readily available by a system of parkways and causeways to some 3,000,000 people in New York City and 


\section{COASTAL ENGINEERING}

over 2,000,000 more in Nassau and Suffolk counties, a combined total of $10,000,000$ persons.

of the twenty-three miles of beach, fifteen miles are included in state parks under the jurisdiction of the Long Island State Park Commission. The remaining eight miles are owned by the Towns of Bablylon and Oyster Bay. As early as 1936 the Long Island State Park Commission instituted a cooperative study with the Beach Erosion Board of the Corps of Engineers, United States Army with respect to beach erosion control for Jones Beach. Almost continuously since then the beaches and the two inlets have been the subject either of cooperative beach erosion control studies between the Park Commission and/or Suffolk County with the Beach Erosion Board, or relevant navigation reports by the Corps of Engineers concerning the inlet. The most recent report (1) deals with the entire area from Fire Island Inlet westward to Jones Inlet. It contains a list of most of the earlier reports dealing with previous investigations. The present paper describes some of the background and the implementation of certain of the recommendations contained in this report.

In 1926 the area from Jones Inlet east to what is now known as Captree State Park was a series of barrier beaches, shoals, and mud flats. That year marked the inititation of the remarkable developments conceived and carried out in steps ever since under the general direction of Robert Moses, President of the Long Island State Park Commission, and his associates. Some 40,000,000 cubic yards of sand have been dredged from the adjacent bays and lagoons to create an unimpeded stretch of eighteen miles of publicly owned recreational area. The original development along the first six miles resulted in Jones Beach State Park. This became so intensively used that other parks were developed to the east. A four lane highway extends for the length of the region, constituting a "backbone fill" with elevation fourteen feet above MSL. Included in the developments are parking fields with a capacity of 40,000 cars per day. The total cost of all of the developments exceeds $\$ 50,000,000$, a public investment warranting substantial expenditures for protection against ravages from waves and storms, including beach erosion.

Not withstanding the magnitude of these developments, they are presently taxed to capacity. On a fine Sunday in sumer the beaches are visited by over 200,000 people, and the access causeways have to be closed before noon, as no more cars can be accommodated. Some idea of the situation may be obtained from Figure 3, which is a view from near the eastern section of Jones Beach State Park looking west toward Jones Inlet. Attention is called to the three large parking fields and the two smaller "overlook" parking fields, all filled to capacity. The recently completed Jones Inlet jetty is shown in the distance. Figure 10 shows the newest development at Captree State State Park.

Because of the situation described above, the Long Island State Park Commission has plans under way to construct a bridge from Captree 
SAND TRANSFER, BEACH CONTROL, AND INLET IMPROVEMENTS, FIRE ISLAND INLET TO JONES BEACH, NEW YORK.

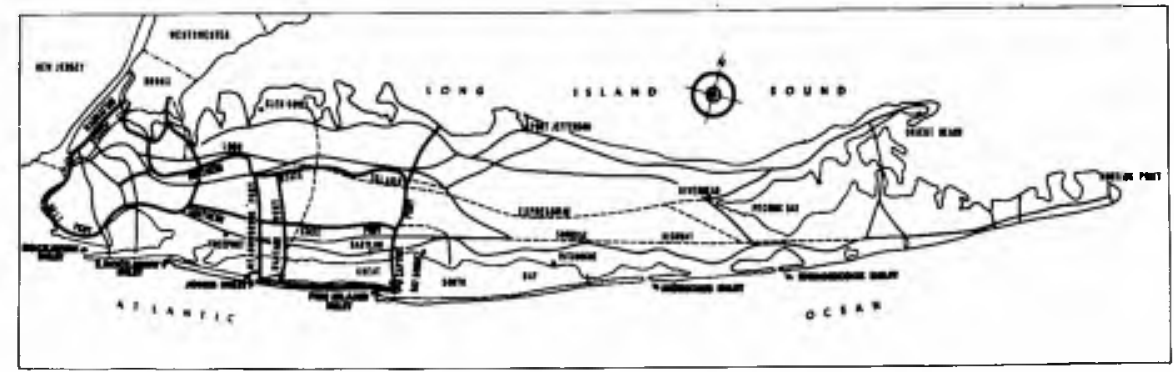

Fig. 1. General map of Long Island, New York.

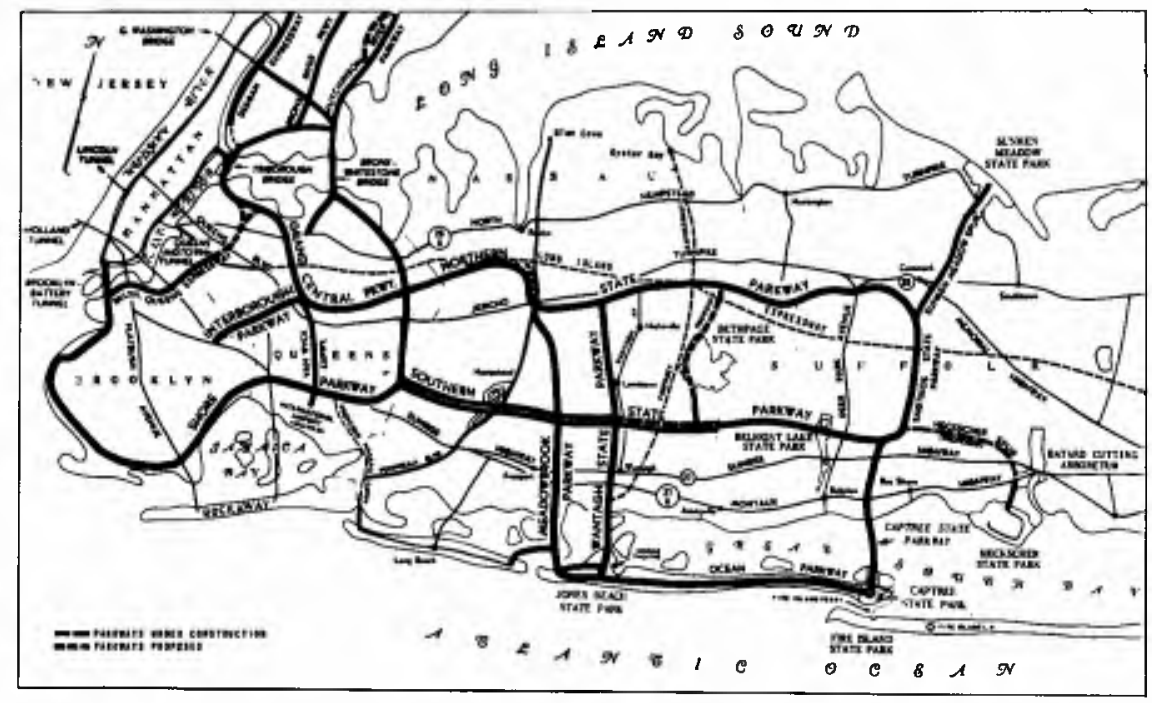

Fig. 2. Western end of Long Island, New York.

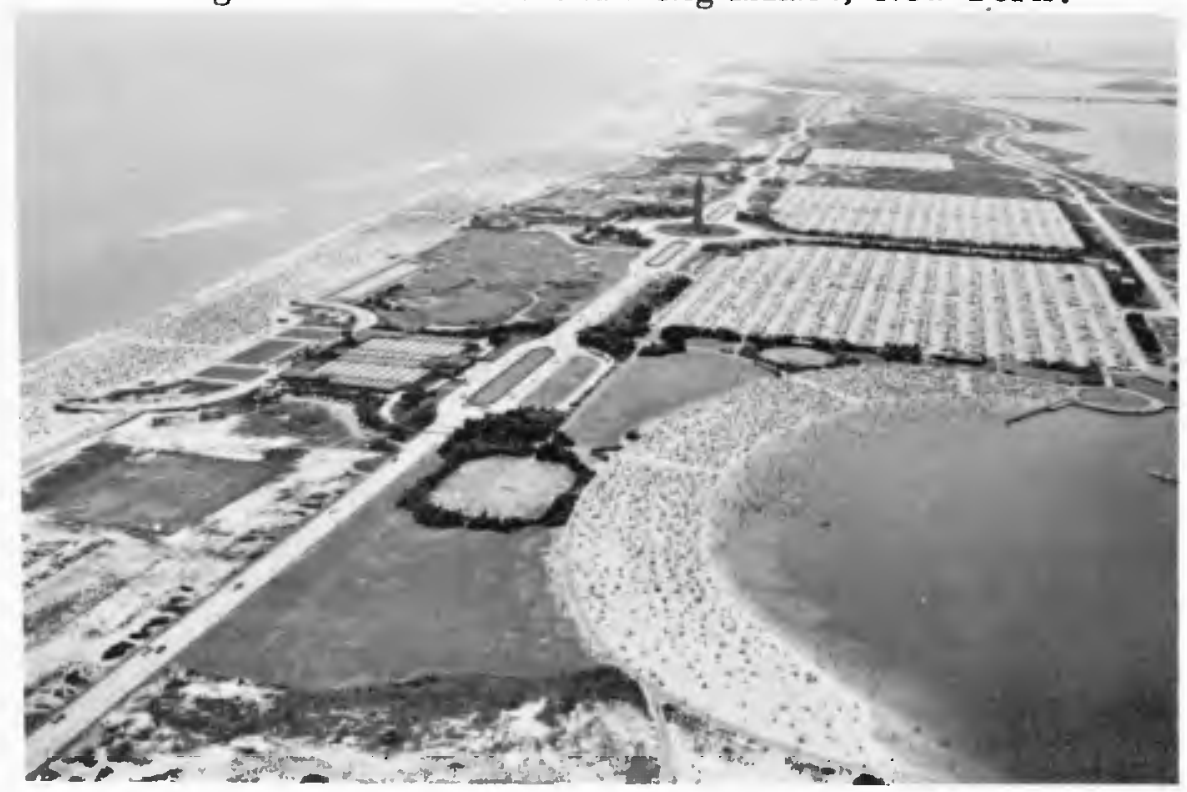

Fig. 3. Jones Beach, New York, lookr ing west toward Jones Inlet. 
COASTAL ENGINEERING

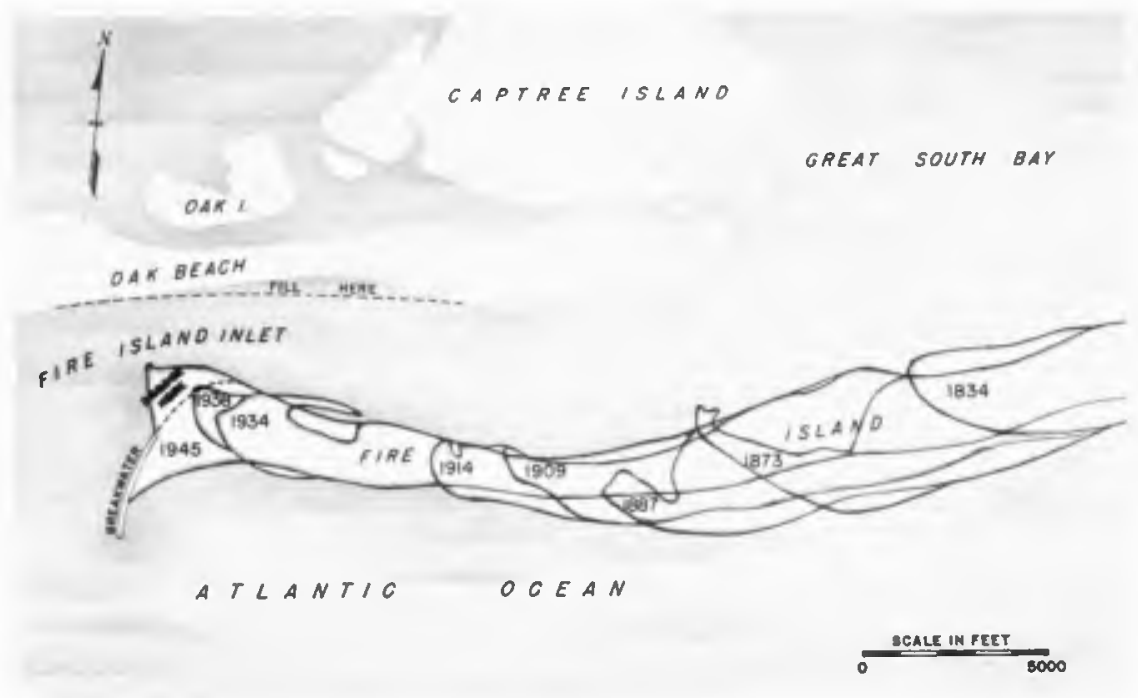

Fig. 4. Progressive westerly movement of Democrat Point.

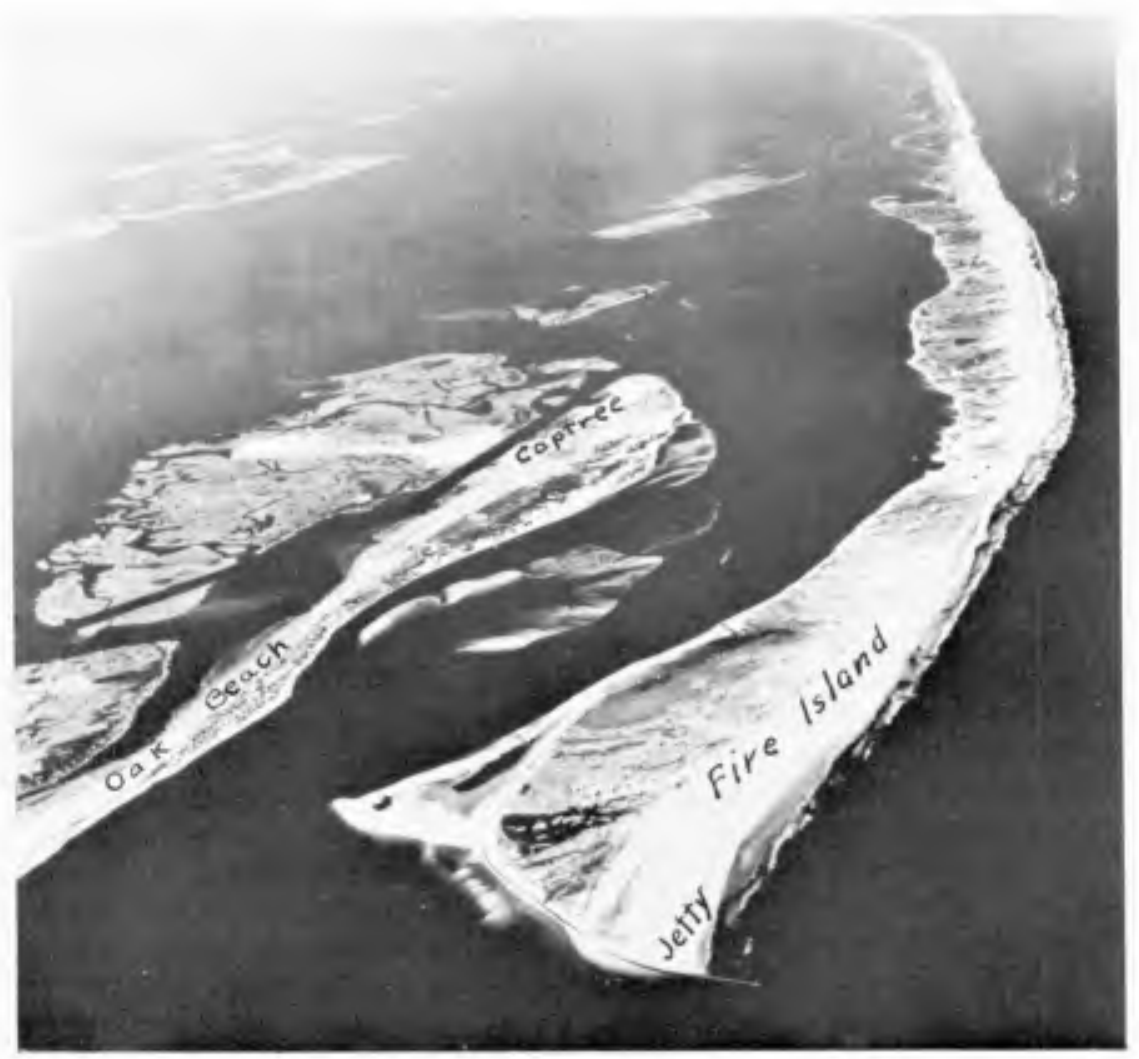

Fig. 5. Fire Island Inlet and jetty in 1948. View to east. 


\section{SAND TRANSFER, BEACH CONTROL, AND INLET IMPROVEMENTS, FIRE ISLAND INLET TO JONES BEACH, NEW YORK}

State Park to Fire Island, and to develop an additional five miles of beach area at Fire Island State Park as indicated on Figure 29.

\section{THE COASTAL ENGINEERING PROBLEM}

STORMS, WAVES, AND TIDES

The area is subject to attack by tropical hurricanes and by extratropical storms known as "northeasters." Great damage to beaches and adjacent structures has occurred from time to time. Naves in the open ocean may be thirty feet high, and ten to twelve feet high as they impinge upon the coast. Normal tides have a mean range of 4.1 feet off Fire Island Inlet, decreasing with passage through the Inlet to 0.7 feet in Great South Bay. Severe storms have produced still water levels of about ten feet above MSL, and it is believed that still water levels of at least fifteen feet might occur if the peak of the storm surge should coincide with high tide. Several studies have been made of storm surges in this vicinity, the most recent of which (2) is that by Wilson. The most severe storm conditions occur from waves created by winds from the north-east to south-west quadrants having a fetch of several hundred miles over the Atlantic Ocean.

\section{LITTORAL DRIFT}

Many studies have indicated a predominant movement of beach material from east to west. The most striking evidence of this is the migration of Democrat Point, the western extremity of Fire Island. Figure 4 shows the movement of this Point from 1834 to 1945 . The Point moved westward a total of $4.6 \mathrm{miles}$ in the period from 1825 to 1940 , as described in detail in an excellent article by Gofseyeff (3) published in 1953. This article presents valuable data with respect to erosion and accretion in the area, and describes the hydrography of the inlet. Between June 1939 and April 1941 the Fire Island jetty was constructed. The impounding capacity of the jetty was reached about 1950, and material began passing around it to form shoals in the inlet. Figures 5 and 6 show respectively the situation at Fire Island Inlet in 1948 before the impounding capacity of the jetty had been reached, and that in 1957 after extensive shoals to the west had formed. Great South Bay is in the background.

Based upon volumetric measurements of accretion on the east side of the Fire Island and other jetties, and rates of erosion of various beaches, it is estimated that the net littoral drift rate averages about 450,000 cubic yards per year. An interesting feature of studies of littoral movement in the area is that measurements of erosion along the south shore of Long Island seem to indicate substantially less sand supply from such sources than is actually impounded by jetties. It is postulated that some portion of the littoral drift has its origin in offshore sources. 


\section{COASTAL ENGINEERING}

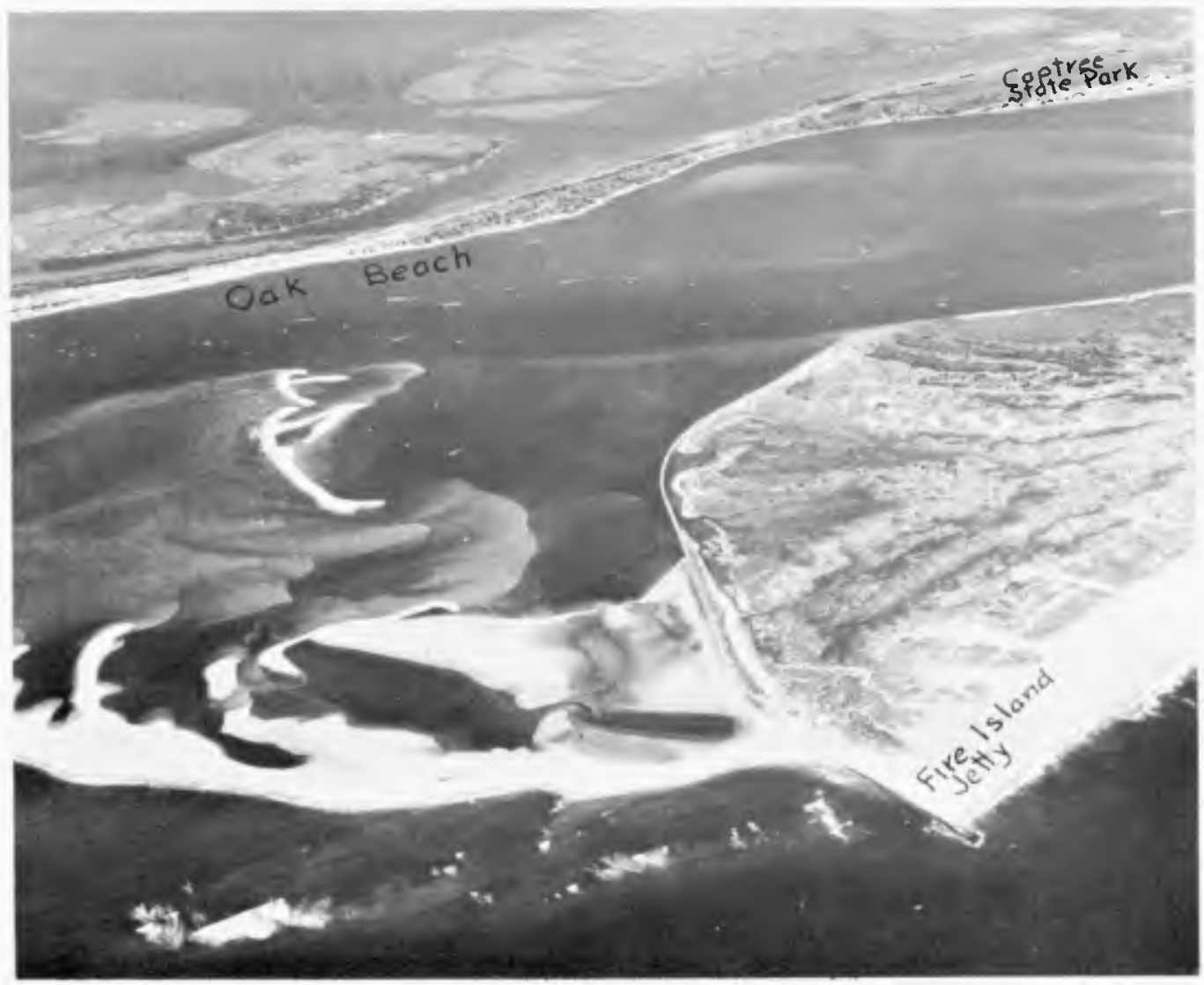

Fig. 6. Fire Island Inlet and jetty in 1957. View to northeast.

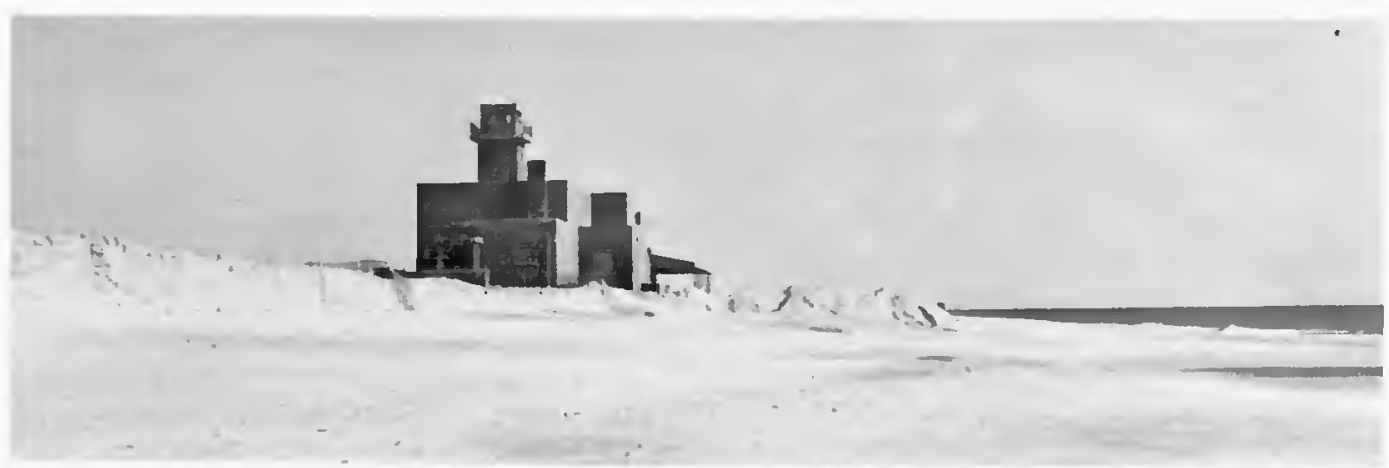

Fig. 7. Erosion at Gilgo State Park pavilion, early 1960. 


\section{SAND TRANSFER, BEACH CONTROL, AND INLET IMPROVEMENTS, FIRE ISLAND INLET TO JONES BEACH, NEW YORK}

\section{BEACH EROSTON}

Genera1. In the problem area substantial 1oss of beaches and damage to adjacent structures has occurred, both under storm conditions and from certain effects induced by the Fire Island jetty. During the last few years serious erosion problems existed chiefly along the highly developed area (Figure 2) from about the center of Jones Beach State Park to Oak Beach, which lies just to the west of Captree State Park. Conversely, impoundment by the Jones Inlet and Fire Island jetties has produced or will produce adequate protective beaches for from four to five miles east of each.

Severe storms always cause substantial erosion and other damage along the beaches. Damage to shore structures is greatly reduced by an adequate protective beach in front of them. Prior to completion of the Fire Island jetty in 1941 and for a few years subsequently, beach erosion over much of the area was not as critical as it became 1ater. Much of the beach loss during severe storms was restored by onshore movement of storm created offshore bars, and by the normal westward moving littoral drift. Sand from Fire Island presumably moved intermittently across the shoals at the entrance to the inlet and nourished the beaches to the west. Local areas of depletion were readily restored by pumping from the bays and channels to the north.

Erosion of the beaches predominates during the months of September to April. During the spring and sumer when relatively quiet ocean conditions exist, with prevailing westerly winds, the direction of 1ittoral transport tends to be reversed to an easterly direction and the updrift eroded beaches to be replenished. The resultant however is a net erosion.

Some years after the completion of the Fire Island jetty the beaches to the west began to indicate accelerated erosion. With curtailment of the previous sand supply from the east, erosion of the beaches west of the inlet* progressed westward with time, threatening Jones Beach. Figure 7 indicates an occurrence in early 1960 at Gilgo State Park about half way from the western side of the inlet to Jones Beach State Park.

Oak Beach. The resort community of Oak Beach (Figures 5, 6, and 10) is located just west of Captree State Park, and a considerable length of the western portion of this beach has been subject to direct attack by storm waves moving into the inlet. It has also been subject to serious erosion from tidal currents in the inlet. The combination of these two factors has caused portions of the western end of the Oak Beach shore to recede to the north about 600 feet from 1930 to 1960. Over forty houses had been destroyed and valuable shore front 1ost. The situation in 1959 is shown in Figure 10. Various photographs of the area accompanying this paper indicate that there was a critical section of shore where erosion had reduced the width of the island to about 600 feet. The main parkway running along this stretch to Captree was in danger of destruction, and the island itself could 


\section{COASTAL ENGINEERING}

have been breached with the formation of a new inlet.

About 1950 sand began passing around the end of the Fire Island jetty, creating extensive shoals to the west and north as shown in Figures 5, 6 , and 10 . Several million cubic yards of material were thus accumulated. As the shoals progressed northward, the main channel of the inlet was also forced to the north and west. Close to the Oak Beach shore the channel had depths up to 50 feet and tidal velocities of six to seven feet per second. At various intervals from 1946 to 1959 more than a million cubic yards of sand were pumped onto the Dak Beach shore to try to restore it. In each case the fill was soon eroded by tidal currents in combination with occasional storm wave action.

\section{MAJOR ELEMENTS OF THE PROBLEM}

The situation described above posed five major problems for which solutions were sought by the cooperative study between the Long Island State Park Commission and the U. S. Army Corps of Engineers.

a. To stabilize and to replenish as far as practicable the beaches from the ocean entrance to Fire Taland Inlet westward to Jones Beach.

b. To partially restore Oak Beach.

c. To stabilize Oak Beach by relieving the pressure of tidal currents impinging upon it, and thus reduce the danger of a breach across the parkway to the back bay, and the possible formation of a new inlet.

d. To reduce maintenance of the navigation channel in Fire IsIand Inlet by reducing the rate of shoaling.

e. To improve the navigation channel by some realignnent.

While the last two items were not specific objectives of the study as originally formulated, they inevitably arose as the study proceeded and the recommendations arising out of it began to be implemented.

\section{RECOMENDATIONS OF THE STUDY}

In accordance with usual practice, the necessary field studies and initial report were assigned to the District Engineer of the $U$. S. Army Corps of Engineers at New York. The staff of the Beach Erosion Board participated in the analysis of the problem and in certain of the solutions recommended. The initial report was revieved by the Division Engineer of the U. S. Axmy Corps of Engineers, North Atlantic Division, and by the Beach Erosion Board. The final 


\section{SAND TRANSFER, BEACH CONTROL, AND INLET IMPROVEMENTS, FIRE ISLAND INLET TO JONES BEACH, NEW YORK}

reconmendations were endorsed by the Long Island State Park Commission, approved by the Chief of Engineers, U. S. Army, and adopted by the Congress of the United States.

The report of the District Engineer proposed two alternative plans, designated respectively the "Comprehensive Plan" and the "Alternative Short-Range Plan." These plans vere proposed after consideration of other alternatives involving design and use of a shallow-draft dredge to excavate material from the shoals and to transport and discharge it upon the beaches; land haul of sand from the impounding area east of the jetty to a point near the inshore end of the jetty, and transfer onto the beaches across the inlet by pipe line dredge or a fixed by passing plant; and construction of an offshore breakwater 1,000 feet long east of the jetty to form a littoral reservoir from which sand would be pumped to the beaches. Each of these latter alternatives was rejected from the standpoint of cost as well as other considerations.

\section{THE COMPREHENSIVE PLAN}

This plan was to be undertaken in three phases, of which thase one (Figure 8) encompassed: (a) Dredging by pipe line dredge an access channe1 into the accretion area east of the jetty; (b) dredging a littoral reservoir as shown on the sane figure; (c) pumping across the inlet one million cubic yards of dredged material a distance of about 20,000 feet to a feeder beach to provide a threeyear source of material for beaches to the west; (d) purping $1,550,000$ cubic yards of dredged material on Oak Beach; (e) closing the access channel with dredged material; (f) removing the dredge through an exit cut 200 feet wide into the Atlantic Ocean; and (g) leaving a barrier on the south side of the lagoon about 150 feet wide and 9 feet above MLW. It was anticipated that the barrier beach would be removed by erosion due to natural forces, leaving a littoral reservoir having a capacity of about two million cubic yards. This procedure was modeled after a somewhat similar scheme carried out at Port Hueneme, California.

Phase two of the Comprehensive Plan provided for a model study of the general beach erosion and navigation problems at Fire Island Inlet. The model study was estimated to require three years. Phase three, subject to the findings of the model study, was to restore the shore line west to Jones Beach as it existed in 1939; restore fill that would have been eroded from Oak Beach; relocate the navigation channel; and repeat dredging of the littoral reservoir to replenish the feeder beach.

The Beach Erosion Board noted the following objections to the "Comprehensive Plan": (a) that a considerable portion of the fill on the Oak Beach shore would be lost by erosion in the absence of provisions to relieve the pressure of tidal currents on that shore; (b) that the model study was not essential in connection with the imnediate problem of beach erosion control, although desirable in connection with future navigation improvements, (c) that full restoration of the 1939 shore line was not regarded by the Long Island 


\section{COASTAL ENGINEERING}

State Park Commission as immediately necessary, but that progressive restoration over a period of years would suffice; (d) that the possibility existed that the exit cut through the barrier beach would close, thus preventing the reservoir from acting as an impounding area and leaving a lagoon as an undesirable feature in the proposed extension of Fire Island State Park; (e) and that full implementation of this plan was estimated to cost about $\$ 2,000,000$ more than the "Alternative Short Range Plan."

\section{THE ALTERNATIVE SHORT RANGE PLAN}

This involved beach restoration and control by dredging material from the existing shoals west of the jetty, and pumping it to the feeder beach and to Oak Beach in a series of operations over a fifteen year period. Phase one of this plan (Figure 9) contemplated excavation by pipe line dredge of 2,000,000 cubic yards from the northwest portion of the shoals; pumping 1,500,000 cubic yards of this to the feeder beach; and pumping 500,000 cubic yards to Oak Beach. The dredging would tend to move the channel toward the south and east, thus effecting some reduction in the pressure of tidal currents along Oak Beach. It was anticipated that the new channel would require an additional 200,000 cubic yards to be removed by hopper dredge. These operations would be repeated at intervals of five and ten years respectively.

The reviewing authorities, including the Beach Erosion Board, favored the foregoing plan, but recognized that conditions might alter between the submission of the report and its adoption by Congress, or during the progress of the work. Hence they recommended some flexibility in the execution of the plan. In his letter transmitting the report to Congress the Chief of Engineers recommended adoption of this plan as outlined by the Beach Erosion Board with such modifications of the plan as in the discretion of the Chief of Engineers may be advisable. The wisdom of the underlined phrase will become evident subsequently.

In its review of the project the Beach Erosion Board stated its opinion that (a) "no fill should be placed on Oak Beach until the pressure of tidal currents on oak Beach can be relieved," and (b) that the plan was "predicated upon future development of a permanent by-passing system for subsequent maintenance."

\section{EXECUTION OF THE PROJECT}

The project was authorized by Congress in July 1958, and the District Engineer at New York proceeded to prepare plans and specifications for the work. During this period, and in accordance with the discretion given to the Chief of Engineers to modify the details of the plan, it was jointly agreed between the Corps of Engineers and the Long Island State Park Commission that instead of dredging the fillet at the end of the shoals shown in Figure 9, there should be substituted a straight cut through 
SAND TRANSFER, BEACH CONTROL, AND INLET IMPROVEMENTS, FIRE ISLAND INLET TO JONES BEACH, NEW YORK

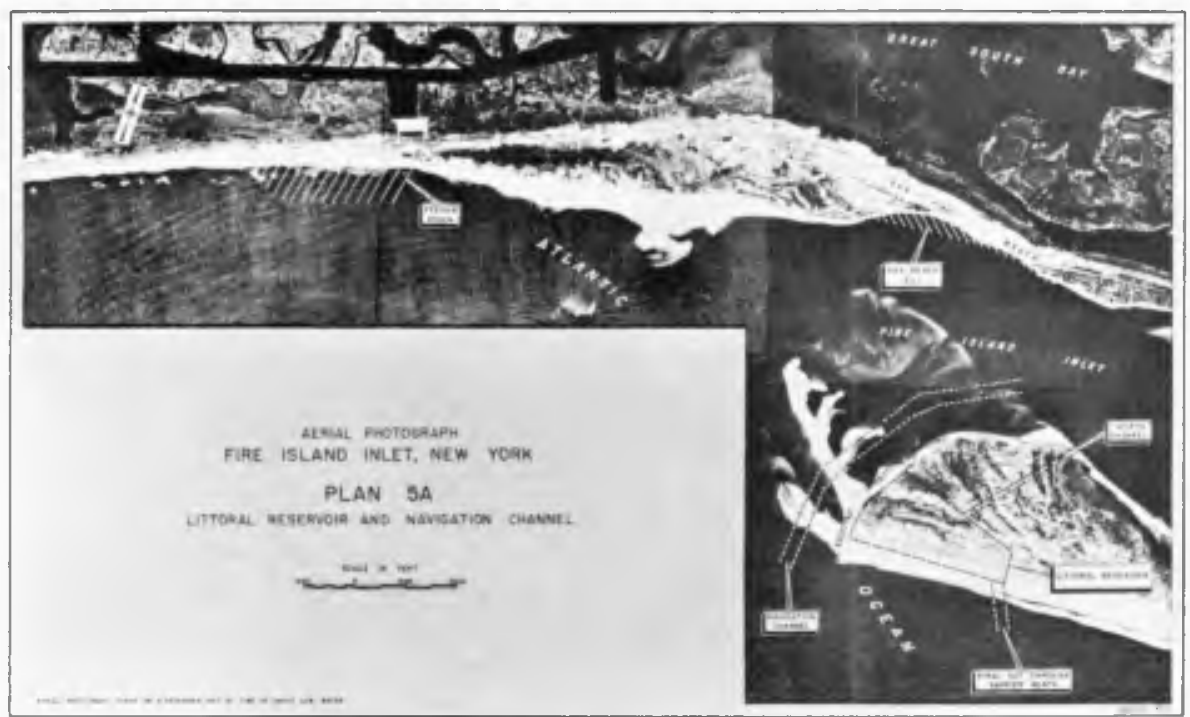

Fig. 8. Phase 1 of "Comprehensive" plan.
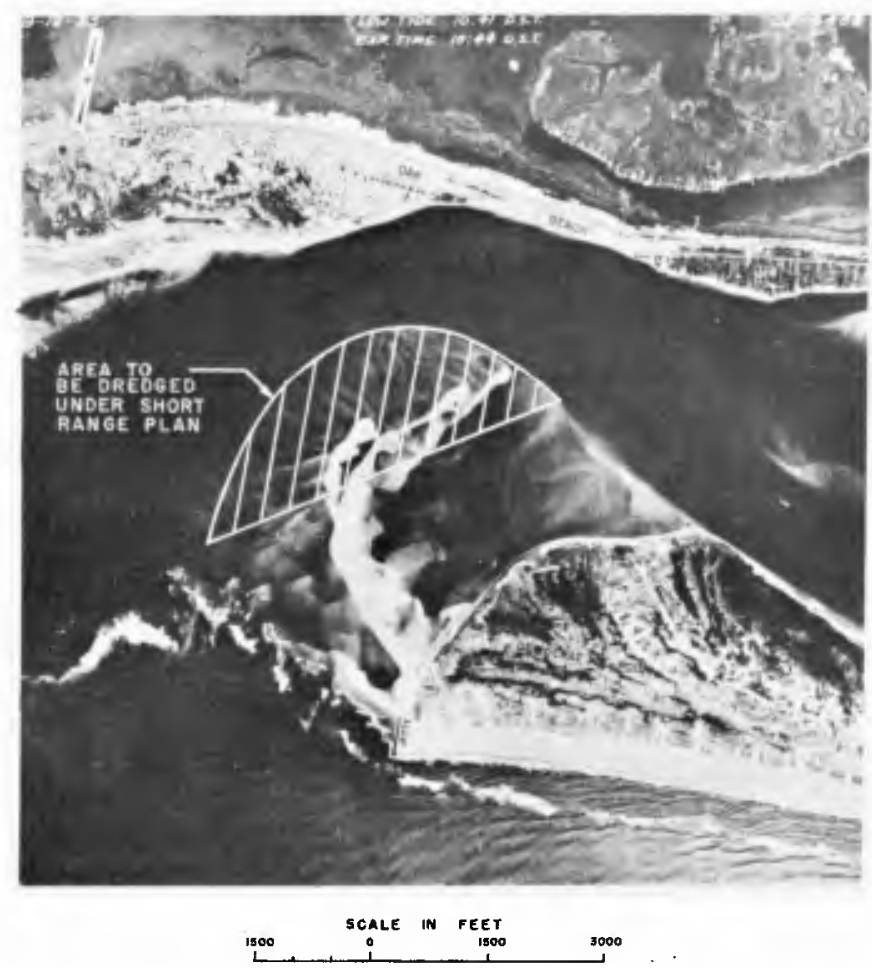

AER IAL PHOTOGRAPN, FIRE ISLAND INLET, N.Y.

Fig. 9. Phase 1 of "Alternative Short Range" plan. 
COASTAL ENGINEERING

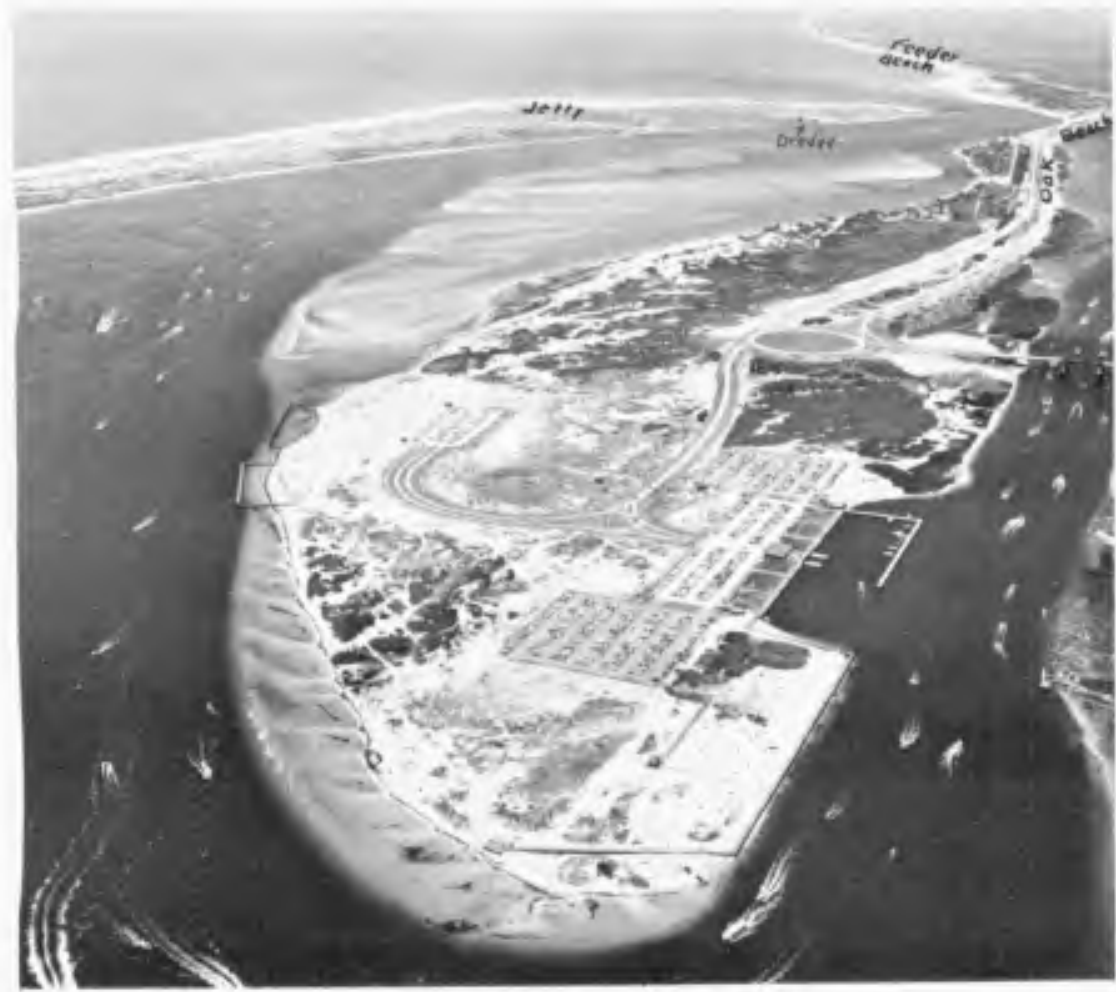

Fig. 10. View looking southwest from Captree State Park.

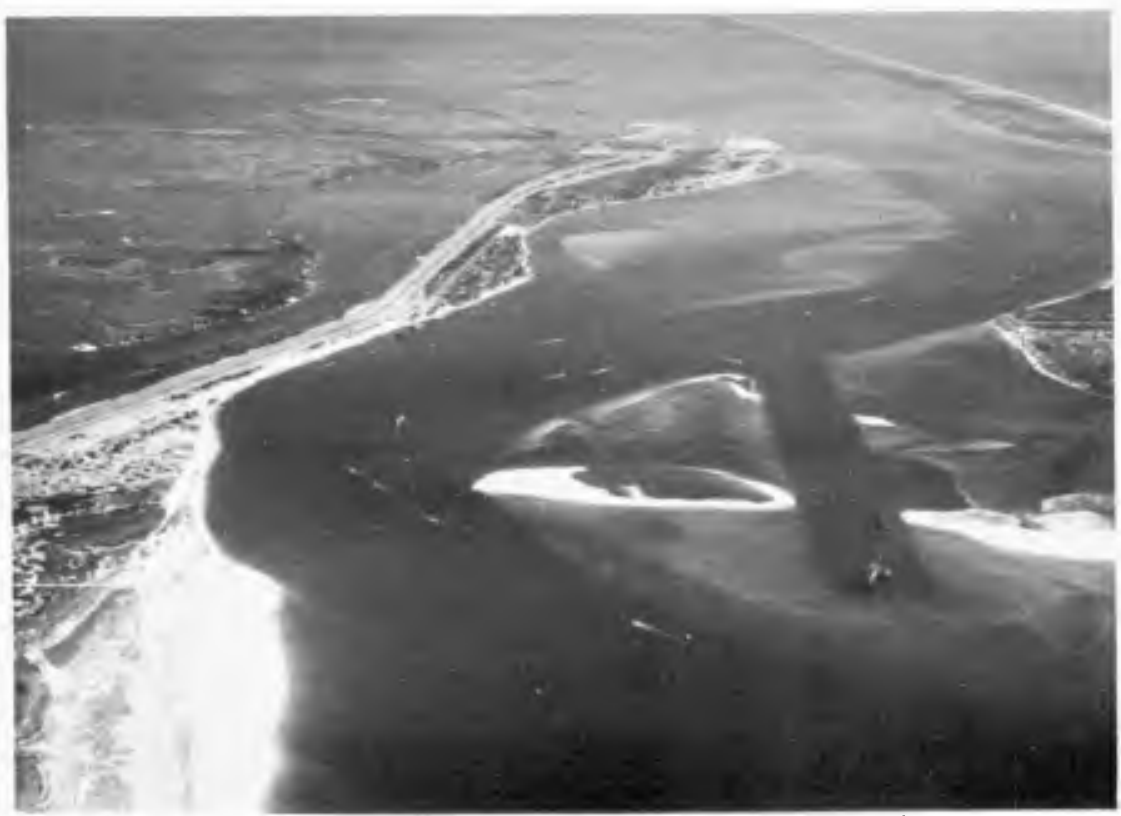

Fig. 11. The new cut, dredge, and discharge line, September 1959. 


\section{SAND TRANSFER, BEACH CONTROL, AND INLET IMPROVEMENTS, FIRE ISLAND INLET TO JONES BEACH, NEW YORK}

the shoals further to the west. Figure 10 is a view looking southwest from Captree State Park in July 1959. The dredge is shown starting the cut through the shoals west of the jetty. Fire Island appears in the upper center. The old channel and Oak Beach appear at upper right. The nearly completed cut, looking northeast, is shown in Figure 11. It was felt that the straight cut would give greater assurance of removing the tidal pressure from Oak Beach. It was the writer's opinion that this would also produce improved operating conditions for the dredge and hence probably a reduced cost. It was believed that no hopper dredging would be required, which proved to be the case. The cut was to be approximately 1,000 feet $(300 \mathrm{~m}$.) wide, by 18 feet $(4.7 \mathrm{~m})$. deep and 6,700 feet $(2 \mathrm{~km}$.) long, with 2 feet overdepth dredging permitted. The contractor was paid on the basis of yardage removed.

The Dredge "Western Chief" of the Western Contracting Company began excavation in June 1959. This is one of the largest dredges in the United States (Figure 12) with $36^{\prime \prime}$ suction, and $30^{\prime \prime}$ discharge. The power plant totals $11,500 \mathrm{H}$. P. of which $6,000 \mathrm{H}$. P. are for the pumps. At an average of $15 \%$ solids, the dredge delivered 1,470 cubic yards (1131 cu. m.) of sand per hour. The maximum distance pumped to the feeder beach was 3.5 miles or 5.5 Kilometers. During the maximum pumping distance a booster purm on land was used to increase the output and to reduce wear on the pump impellers. Figure 11 shows the dredge in the new cut, and the discharge 1ine across the old channel and along Cedar Beach in the direction of the feeder beach.

\section{THE FEEDER BEACH}

The location and approximate dimensions of the feeder beach, shown on Figure 8, was determined after considerable study of refraction diagrams and hydrographic data by engineers of the Beach Erosion Board and the District Engineer's office. The location chosen was the nearest point to the inlet which would permit an estimated 90 per cent of the wave energy to tend to move material to the west. Although the plan provided for $1,500,000$ cubic yards of fill on the feeder beach, the elimination of the necessity for hopper dredging and lower unit prices for dredging than had been anticipated permitted nearly 2,000,000 cubic yards to be deposited between June and December 1959. Figure 13, looking east, shows the feeder beach in process of construction, the discharge line from the dredge, and the dredge in the upper right. Figure 14, from the opposite direction, shows the dredge excavating the cut, and the feeder beach. Figure 15 shows the discharge end of the pipe line in operation.

\section{CLOSURE OF THE OLD CHANNEL}

Following the decision to modify the original plan by constructing a new channel, it became evident that the full benefits desired would not be accomplished if the old channed remained. The flow in two channels would reduce the scouring velocity in each, and hence increase the rate of shoaling. Most important, should the new channel become shoaled so that flow through it was substantially reduced, the earlier 
COASTAL ENGINEERING
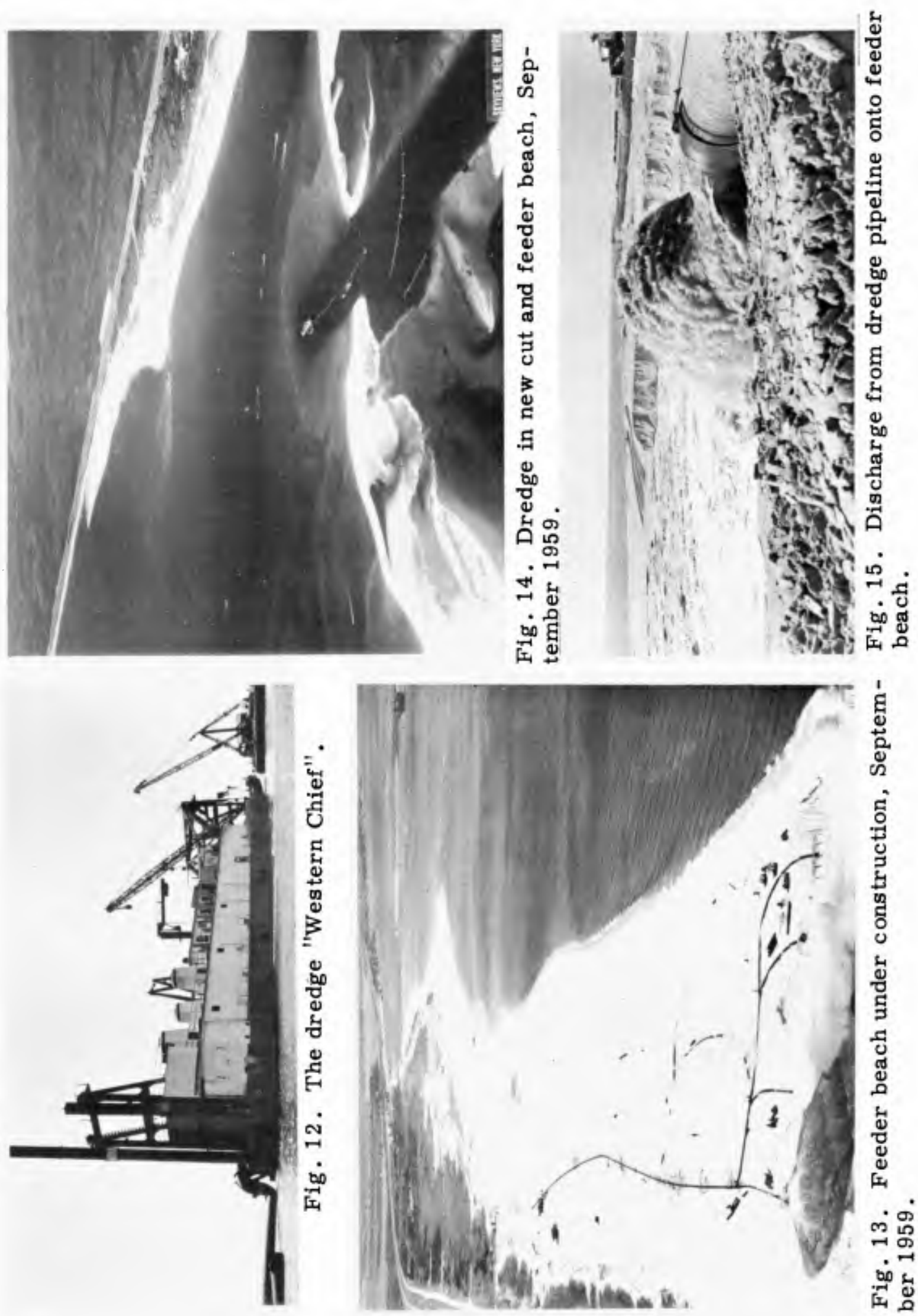


\section{SAND TRANSFER, BEACH CONTROL, AND INLET IMPROVEMENTS, FIRE ISLAND INLET TO JONES BEACH, NEW YORK}

conditions would tend to recur, with renewed tidal pressure against the Oak Beach shore. Since ample material existed in the shoals where the dredge was working, it was decided to close the old channel by a sand fill. Some questions were raised as to whether a closure could be effected by this means on account of the high velocities likely to be encountered in the final stages of the work. Expert advice was to the effect that this could be done, especially considering the high rate of sand transport possible with the dredge, and with some help from landplaced fill from the shore.

Fill for the final stages of the closure began to be placed by the dredge from the remnant of the shoal, west of the new cut at noon on December 3, 1959 (Figure 16) and closure was substantially effected (Figure 19) at low tide about 5:45 p.m. on December 4. The closure became fully effective to 12 feet above MLW (Figure 20) by 10:00 a.m. on December 5 . The short land fill (Figure 17) from the west side was directed somewhat to the north of the axis of the oncoming dredged fill, so that an overlap effect resulted. Velocities prior to closure reached five to seven feet per second, but with the relief provided by the new channe1, this situation lasted only a short time. In the final stages of the closure velocities may have reached as much as ten feet per second. Figures 21 and 22 show the completed closure fill with the new channel fully operative. It is interesting to compare Figures 10 and 22, taken before and after the completion of the work described herein. Figure 23 shows the cross sections and velocities in the old channel before closure and in the new channel after the old channel had been closed. Comparative measurements made in the old channel on August 1959 and in the new channel in August 1960 indicate that the cross section, velocities, volume of flow, and tidal ranges are substantially the same in the new channel as they were in the old channel.

\section{OAK BEACH}

Reference has been made to the recommendation of the Beach Erosion Board that no fill should be placed on Oak Beach until pressure of the tidal currents had been relieved. This had now been accomplished by the closure of the old channel and by the change in direction of the tidal currents after construction of the new channel. In addition the closure fill would protect the critical areas of Oak Beach from the severity of attack by storm waves previous1y experienced. Therefore about 600,000 cubic yards were pumped to the western portion of Oak Beach by the dredge Western Chief as part of the contract in order to provide immediate protection to the adjacent structures, including houses and the parkway. In addition the Long Island State Park Commission constructed a series of short and light stone groins along the eastern portion of the affected area, and subsequently arranged for a smaller dredge to pump some 600,000 cubic yards of sand fill along this shore as a continuation of the work done by the Western Chief. Figures 24 and 25 show the before and after conditions looking west from about the center of the Oak Beach Shore, and figures 26 and 27 show a similar comparison looking east from about the same point. 
COASTAL ENGINEERING
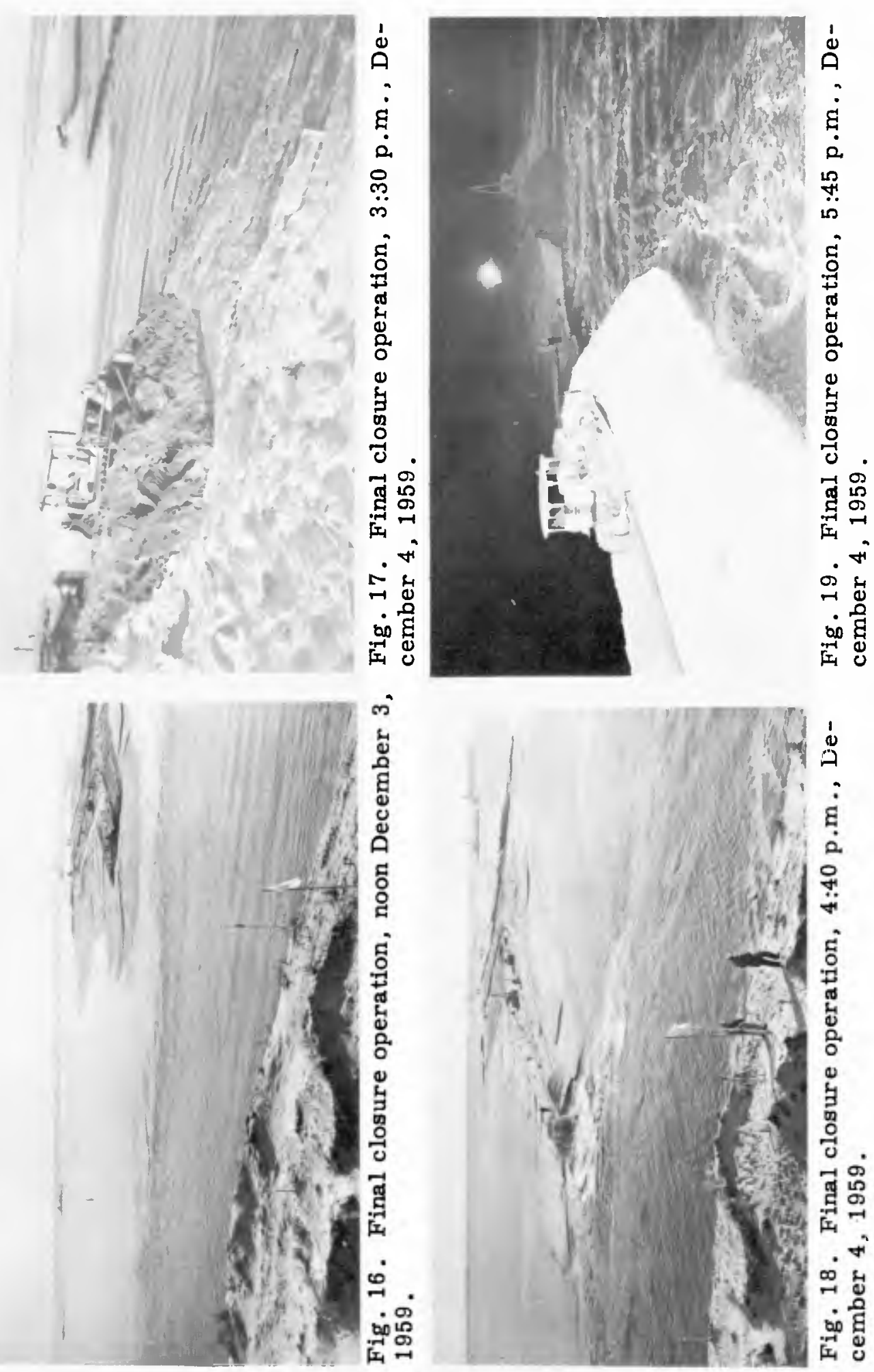
SAND TRANSFER, BEACH CONTROL, AND INLET IMPROVEMENTS, FIRE ISLAND INLET TO JONES BEACH, NEW YORK

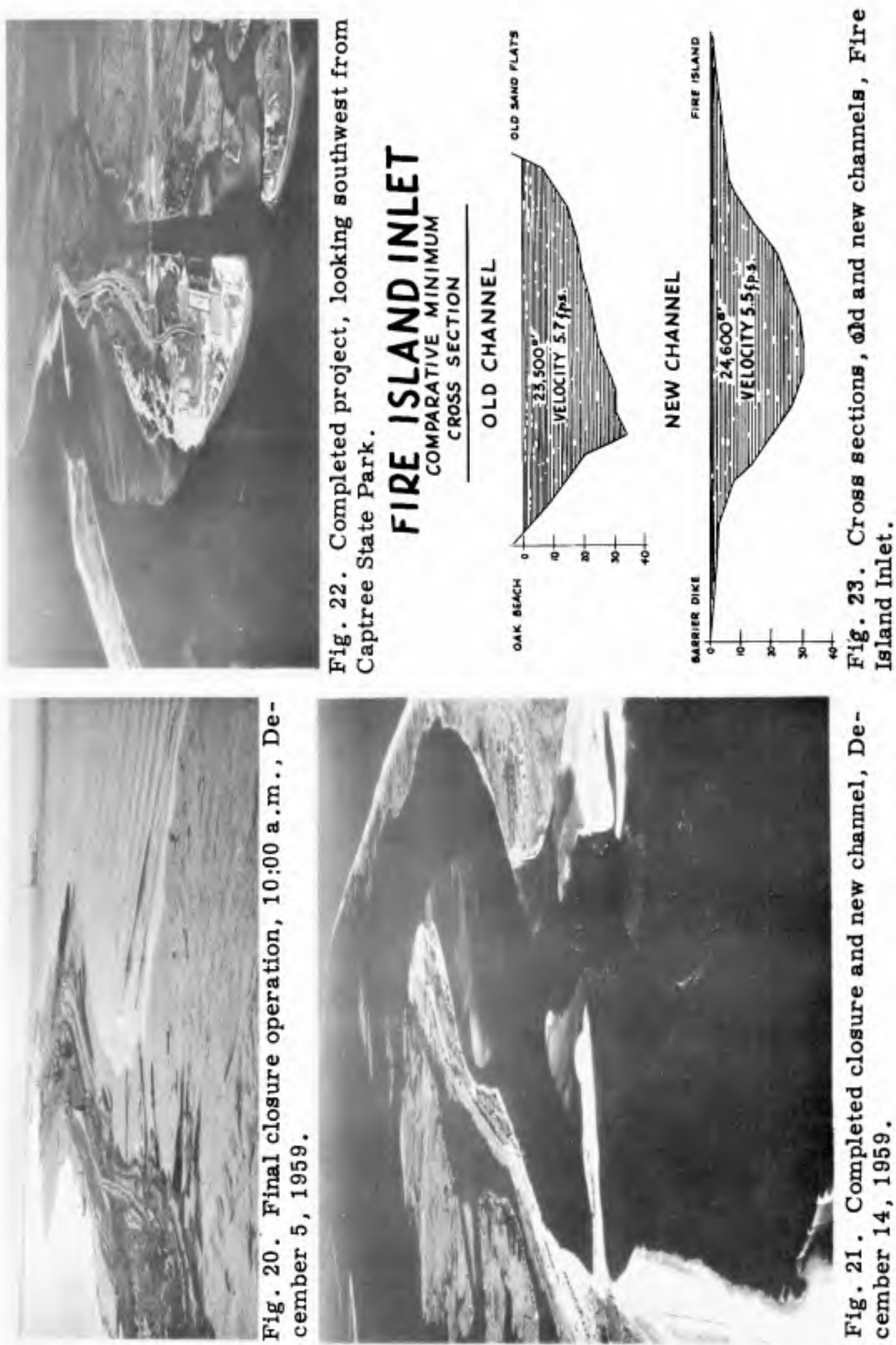


COASTAL ENGINEERING
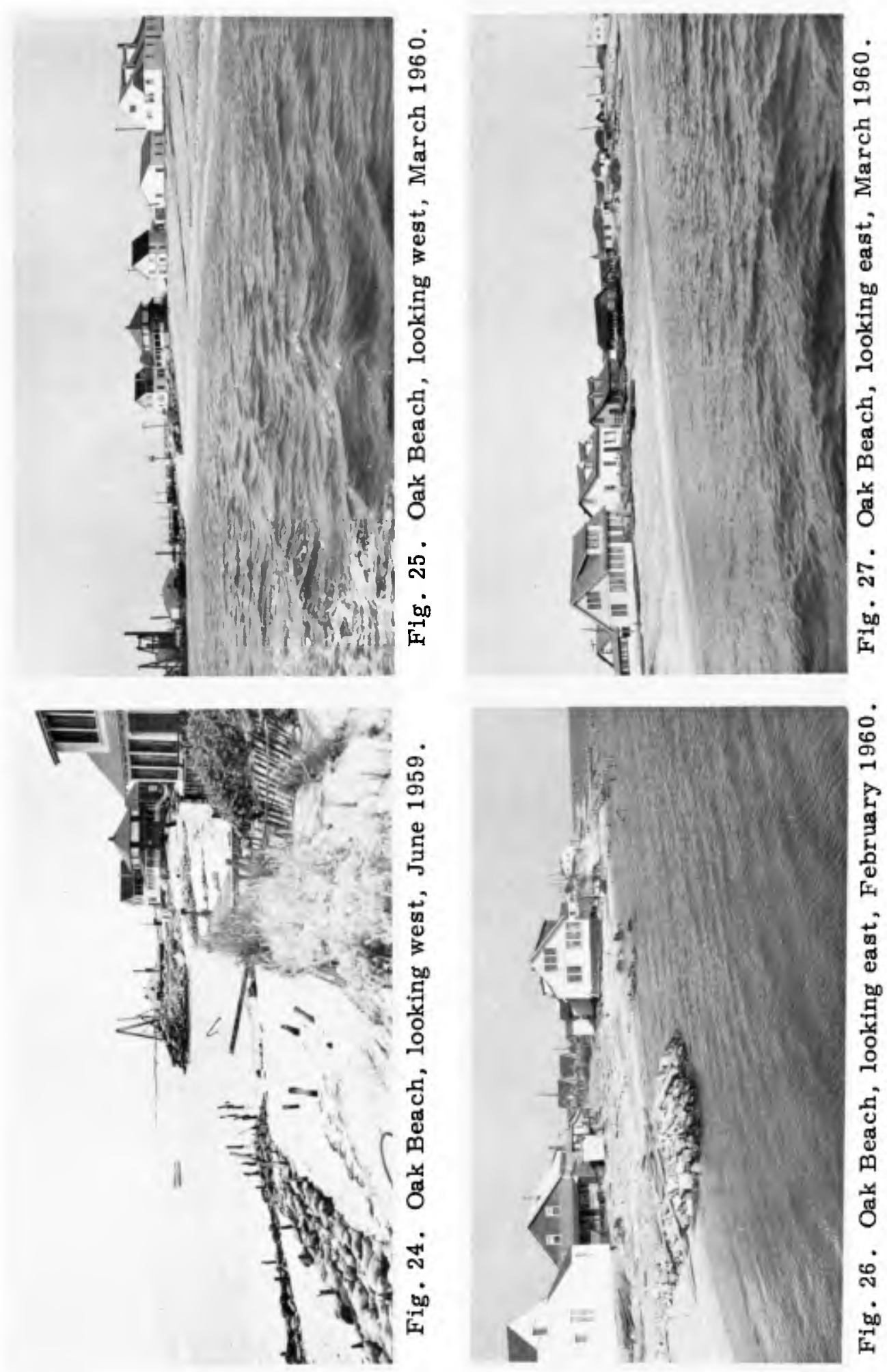
SAND TRANSFER, BEACH CONTROL, AND INLET IMPROVEMENTS, FIRE ISLAND INLET TO JONES BEACH, NEW YORK

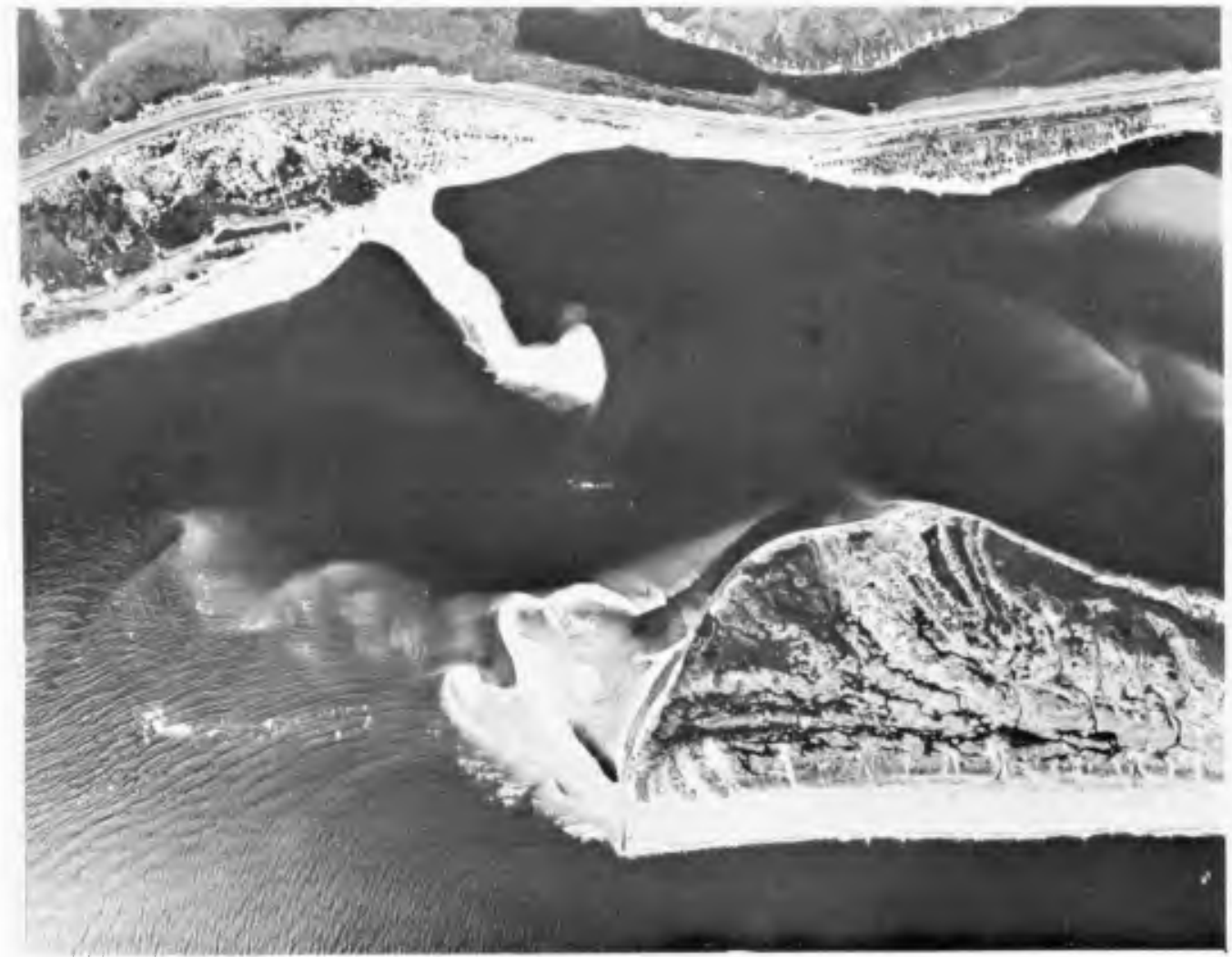

Fig. 28. Closure fill after Hurricane Donna, September 1960.

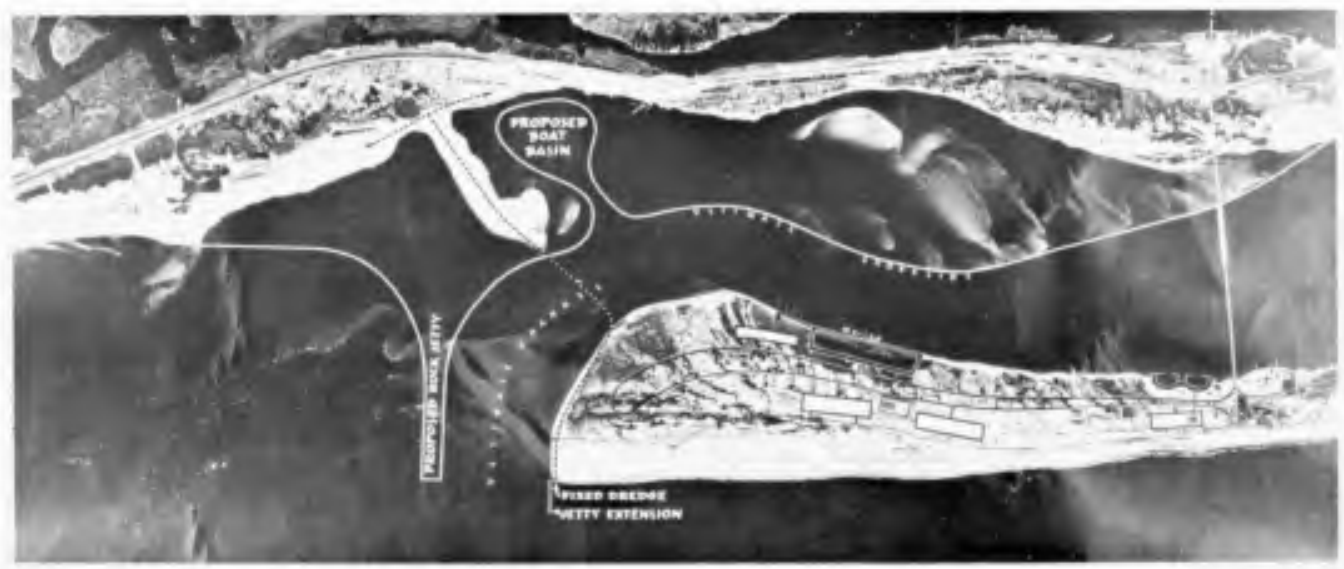

Fig. 29. Tentative plans of the Long Island State Park Commission for future development in the vicinity of Fi re Island Inlet. 


\section{COASTAL ENGINEERING}

\section{APPROXIMATE VOLUMES OF FILL PLACED}

By dredge "Western Chief", Government contract

On Feeder Beach
On closure Fil1
On Oak Beach

Total contract pumping

By Long Is land State Park Commission and Suffolk County

On Oak Beach

Grand total
$1,930,000$ cubic yards

$1,325,000$ cubic yards

500,000 cubic yards

$3,755,000$ cubic yards

600,000 cubic yards

$4,355,000$ cubic yards

It should be noted that the volume of fill under Phase one materially exceeded that suggested in the original plan, but that in spite of this the work was completed at about the authorized cost. This was due in part to a lower price than originally contemplated for the large dredge, and in part because the Long Island State Park Commission required excavation for its own purposes in the bay north of Oak Beach, and little or no additional cost was involved in disposing of the dredged material along the Oak Beach waterfront.

\section{STRENGTHENING THE CLOSURE FILL}

The fill closing the old channel was considered to be a vital element in the entire program. Constructed entirely of sand to a height of about fifteen feet above MSL, and exposed to the full attack of storm waves from the ocean, it was felt that it should not only be protecterl on the ocean side, but that its general dimensions should be maintained as currents and erosion tended to chance them. The Commission therefore has performed minor operations with bull-losers to restore the profile of the fill as wind, waves, and currents have tended to modify it, and has constructed a series of short and light stone groins on the ocean side. It plans to continue such moderate protective works as material for armoring the ocean slopes can be obtained at merely the cost of hauling, as was done at Oak Beach.

\section{TEST OF THE PROJECT}

The works previously described were completed in August 1960. In September Hurricane Donna passed over the area. All of the works functioned as intended. Material from the feeder beach moved westward; the closure fill (Figure 23) was not damaged seriously; and the Oak Beach shore was fully protected. The latter event stimulated various laudatory letters from residents of Oak Beach who had suffered severe damage from most previous hurricanes. 


\title{
SAND TRANSFER, BEACH CONTROL, AND INLET IMPROVEMENTS, FIRE ISLAND INLET TO JONES BEACH, NEW YORK
}

\author{
CONCLUSTONS
}

\begin{abstract}
Experience to date indicates that the basic plan recommended by the Beach Erosion Board was well adapted to its purposes. As previously indicated, phase one of the project was completed at less than the authorized cost. The actual cost of the work performed under government contract was $\$ 2,484,000$ at an average cost of 66 cents per cubic yard. Including government costs the total cost was $\$ 2,678,000$. Apportionment of project costs are $42 \%$ to the United States and $58 \%$ to the state and county. The usual division for beach erosion control projects involving publicly owned lands is $1 / 3$ by the United States and $2 / 3$ by local interests, but in this case the United States assumed an additional share on the basis that consumation of the project would reduce navigation maintenance costs. The local agencies advanced $\$ 152,880$, subject to later reimbursement, to assure completion of the required yardages.
\end{abstract}

One element of the program deserves to be mentioned again, namely the provisions that the basic plan could be modified in the discretion of the Chief of Engineers. The flexibility thus male possible, whereby the Army Engineers and the cooperating agency (the Long Island State Park Commission) could agree on changes, produced an ultimate solution which, in the opinion of the writer, was much superfor to what would have resulted if rigid adherence to the original plan had been required. The rather unusual cooperative features of the Beach Erosion Act were doubtless devised with such possibilities in mind.

\section{THE NEXT STEP}

As the Beach Erosion Board stated in its report, the ultimate success of the combined beach erosion control and navigation problems is likely to depend upon the development of a suitable sand by-passing plant to intercept sand moving from the east toward the Fire Is ind jetty and to transport it to strategic locations across the inle:. Fully persuaded of the validity of this suggestion, the Long Island State Park Commission as early as 1956 engaged a well known consulting engineer, Frederick H. Dechant of Harris-Dechant Associates, to render a report on a fixed sand by-passing plant. Various designs were proposed, and the latest submitted in 1959 describes a plant located east of the jetty and consisting of a fixed trestle mounting two traveling bridges. Suspended from the lower girders of the bridges are the dredge pumps, one on each bridge which travels back and forth on the girders. The pumps are designed to excavate a trench 500 feet long, 25 feet wide at the bottom, and to a depth of 16 feet below MSL. The dredge pumps discharge to vells from which sand is pumped to a main pumping station from which it would be pumped across the inlet.

Since completion of the work described in this paper, the Long Island State Park Commission has submitted to the Army Engineers a proposal for a special investigation to determine the best method 


\section{COASTAL ENGINEERING}

of effecting sand transfer across the inlet. It is assumed that the Dechant proposal will be considered, among other designs, in the course of such a study.

\section{THE ULTIMATE PLAN}

Granted the apparent success of the work constructed to date; granted the design and installation of an efficient and economical sand transfer plant; one asks "what happens to the extensive shoals remaining west of the jetty, and their relation to an improved navigation channel?" Figure 29 shows the long range tentative plans of the Long Island State Park Comnission, which envision dredging the existing shoals to create fill to the east for the enlarged and improved Fire Island State Park referred to earlier in this paper. The present closure fill would be fired and incorporated into extensive new land to be created between it and Captree State Park. A small boat marina is shown, and is likely to be one of the early projects in this program. The navigation channel would be moved eastward toward the jetty, and be fixed in position by the adjacent structures. If and when this plan is executed, or some modification of it approved after investigation by federal and state authorities, it is hoped that the Fire Island Inlet Problem, including sand transfer, navigation, and related recreational benefits will be solved.

\section{ACKNOWLEDGEMENTS}

During the course of the studies and the work reported in this paper the following principal officials of the two cooperating agencies were directly involved. In addition, as usual in such cases, most of the basic studies were performed by numerous able engineers on the staffs of these agencies.

CORPS OF ENGINEERS, U. S. ARMY

Lieutenant Generals S. D. Sturgis, Jr., and E. C. Itschner, Chiefs of Engineers. Major Generals Chas. G. Holle and W. K. Wilson, Jr. and Brigadier General T. D. Weaver, Presidents of the Beach Erosion Board. Brigadier Generals Clarence Renshaw and T. H. Lipscomb, Division Engineers, North Atlantic Division. Colonels J. T. O'Neil, T. De F. Rogers, and C. M. Duke, District Engineers at New York.

\section{LONG ISLAND STATE PARK COMMISSION}

Robert Moses, President. Sidney M. Shapiro, General Manager and Chief Engineer. Richard $C$. Boyce, Deputy Chief Engineer. Thorndike Savilie, Consulting Engineer. 
SAND TRANSFER, BEACH CONTROL, AND INLET IMPROVEMENTS, FIRE ISLAND INLET TO JONES BEACH, NEW YORK

RELERENCES

(1) Corps of Engineers U. S. Army (1957). Cooperative Beach Erosion Control Study, Fire Island Inlet to Jones Inlet, New York. House Document 411, 84th Congress, 2nd Session. U. S. Government Printing office.

(2) Wilson, Basil W. (1960). The Prediction of Hurricane Storm-Tides in New York Bay. Technical Memorandum No. 120, Beach Erosion Board, Corps of Engineers, U. S. Army.

(3) Gofseyeff, S. (1953). A Case History of Fire Island Inlet, New York. Proceedings of Third Conference on Coastal Engineering. Council on Wave Research. 